\title{
Protein Disulfide-Isomerase A3
}

National Cancer Institute

\section{Source}

National Cancer Institute. Protein Disulfide-Isomerase A3. NCI Thesaurus. Code

C112121.

Protein disulfide-isomerase A3 (505 aa, $257 \mathrm{kDa}$ ) is encoded by the human PDIA3 gene.

This protein is involved in both the activity of the MHC class I peptide-loading complex and post-translational disulfide bond formation. 